
and Social Policy

Instructions for authors, subscriptions and further details:

http://rasp.hipatiapress.com

\title{
The Depressed Class of Elderly: Elderly Population Among Lower Income Households in Kolkata
}

Sumita Saha ${ }^{1} \&$ Somrita Sengupta ${ }^{2}$,

1) Presidency University. India

2) Rabindra Bharati University. India

Date of publication: January $30^{\text {th }}, 2019$

Edition period: January 2019- June 2019

To cite this article: Saha, S. \& Sengupta, S. (2019). The Depressed Class of Elderly: Elderly Population Among Lower Income Households in Kolkata. Research on Ageing and Social Policy, 7(1), 285-303. doi: 10.4471/rasp.2019.3921

To link this article: http://dx.doi.org/10.447/rasp.2019.3921

PLEASE SCROLL DOWN FOR ARTICLE

The terms and conditions of use are related to the Open Journal System and to Creative Commons Attribution License (CCAL). 


\section{The Depressed Class of Elderly: Elderly Population Among Lower Income Households in Kolkata}

Sumita Saha

Presidency University
Somrita Sengupta

Rabindra Bharati

(Received: 30 November 2018; Accepted: 12 December 2018; Published: 30 January 2019)

\section{Abstract}

Modernizing trends are changing the nooks and corners of every part of the society, and India is no left behind. The present paper seeks to explore the domain of physical and mental well being of the elderly population among the lower income households in Kolkata. The findings of the paper show that in lower income households, nuclear families values are gradually penetrating, which is transforming the elderly- family interactions. Elderly population who were previously acknowledged as the head of the household or one of the major decision maker are gradually sidelined or excluded from the household affairs. Elderly population face exclusion as well as rejection from family. They are often treated as an unwanted liability, which will be relieved only with their deaths. Case studies of 20 elderly respondents have been taken to explore the physical and mental health of the elderly population among the lower income households.

Keywords: Elderly, lower income households, nuclear families, physical and mental well being 


\section{La Clase de Ancianos Deprimidos: Personas Mayores en Hogares de Bajos Ingresos en Calcuta}

Sumita Saha

Presidency University
Somrita Sengupta

Rabindra Bharati

(Recibido: 30 noviembre 2018; Acceptado: 12 diciembre 2018; Publicado: 30 enero 2019)

\section{Resumen}

Las tendencias de modernización están cambiando los rincones de cada parte de la sociedad, también en la India. El presente artículo explora el dominio del bienestar físico y mental de la población anciana entre los hogares de menores ingresos en Calcuta. Los hallazgos del documento muestran que en estos hogares los valores de las familias nucleares están penetrando gradualmente, lo que está transformando las interacciones entre los ancianos y las familias. A la población anciana, a la que se la reconoció anteriormente como cabeza de familia, se las deja de lado o se los excluye gradualmente de los asuntos del hogar. La población anciana se enfrenta a la exclusión y al rechazo de la familia. A menudo se los trata como una responsabilidad no deseada, que solo se aliviará con sus muertes. Se han realizado 20 estudios de caso a personas ancianas encuestadas para explorar la salud física y mental de la población anciana entre los hogares de menores ingresos.

Palabras clave: Ancianos, hogares de bajos ingresos, familias nucleares, bienestar físico y mental. 


\section{Saha \& Sengupta - The Depressed Class of Elderly}

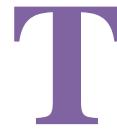

he concept of age has become more complicated because life expectancy has increased and people at each age have had progressively more remaining years of life thus aging has inherently turned into a lifelong process which starts from individual's birth and continues till death. In the yester years, it was apparent that inefficient medical facilities as well as ignorance have been major reasons behind the early deaths. However post 21 st century, there has been a drastic progress in the field of science, medicines and technology which had consequently increased the life expectancy rates. Hence the present reality depicts an inherent rise in the elderly population which if not confronted properly, will turn into a social malady.

Concern for the alarming rise in elderly population became major point of discussion in Lund Declaration of 2009. The United Nations has predicted that by 2050 , one third of the population in developed countries and one tenth of the population in developing countries will comprise of elderly population (United Nations, 2009). Indeed it will be a challenging issue which needs to be addressed skillfully, since aging in other terms also means higher dependency ratio and low manpower viz, low proportion of work force. At the same time, it will also create negative impact on health care infrastructure of various countries. According to data from World Population Prospects: the 2015 Revision (United Nations, 2016), the number of elderly persons has increased in proportion, in the majority of countries and regions, and that growth is probable to accelerate in the coming decades.

Although there has been an inherent rise in senility, in spite of that age has been interpreted in negative fashion in various discourse of gerontology, whereupon approaching to increased age has been exclusively constructed on the parameters of physical and mental deformities as well as a time of loneliness and 'awaiting death phase (Rose, 1991, Sanderson \& Scherbov, 2008). The percentage of aging population has increased in such a drastic rate that it had disturbed the population pyramid model which has changed from conical form to barrel shaped model. Henceforth it has become an urgent need of the hour that the issue of elderly needs to be taken care of. 
It is quite clear that the elderly population is rising at an alarming rate and the world needs to confront it in an effective manner. In this search for effective confrontation of 'alarming aging' we have found that the modern society has gone through a major transition in its values structures. One of the major characteristics of this social change includes the evolution of nuclear family structures followed by the trends of industrialization as well as urbanization. The aftermath of this process are often backed up by various dominating value trends which include ambition, individualism as well as utility structure. Herein the latter meant that individual is often judged on the basis of their contribution to the society, family as well as economy. Thus the modernization theory of aging has stressed on the gradual decline of elderly importance in the society followed by the rising trend of modernity, wherein an individual's importance is based on his/her utility to the society. In this regard, we find that it becomes important that we look into the domain of elderly living condition in consideration to class as an active variable, since care in modern times has become a commodity whose quality as well as accessibility is entirely dependent on affordability factor. In this regard, the present paper, explores the domain of physical and mental well being of the elderly population among the lower income households in the country.

\section{Review of Literature}

Due to the subsequent rise of the elderly population as mentioned earlier, elderly issues has been a subject of international enquiry since the time has arrived that we need to confront the elderly issue in a proper sense. The Department of Economic and Social Affairs, Population Division has stated that Indian elderly demographic scenario has passed the hundred million mark, whereupon they have stressed on the health and welfare state of the senile people, which seemed to be the most important factor in case of the elderly population. While exploring various literature on elderly we see that health, economic status, quality of life comes out to be the major concerns of the elderly population. Health is a significant concern for aged people because they stand at a high risk to suffer from health related problems because of their age. In fact they are vulnerable to various diseases owing to 
degrading immunity. In this regard we can easily say that medical science has drastically progressed which upgraded the longevity ratio, at the same time, longer life is accompanied with numerous diseases often reducing the concept of life without live A long life isn't worth living if the years spent are not satisfactory, where health often becomes a major obstruction in the path as the ability to resist diseases decreases with age, and at times complete cure is just not possible (Chaturbhuj, 1998). With advancement of age, physiological condition also deteriorates, as a result of which body is not able to resist illness. The illnesses which an elderly faces are mostly chronic, and they are affected by more than one number of diseases. Kafle et.al. (2017) has mentioned in their paper that elderly population usually suffer from many chronic health problems like Diabetes, Hypertension, Cardiovascular diseases, Cancer, Arteriosclerosis, kidney diseases, Parkinson's diseases, Arthritis, Dementia etc. The duration of both acute and chronic condition for the elderly is longer and their chronic conditions are more likely to be lethal. Lalitha (2012) in her paper 'Health Aspects of Elderly: A Global Issue' has opined that health is a vulnerable component of elderly people and their every day interaction. In physical aspects, elderly people face various forms of disease which restricts their daily habits. On the other side, senile population is also affected by mental problems wherein dementia is regarded as one of the most common problem of the elderly.

Keyes (2005) in his paper Chronic Physical Conditions and Aging: Is Mental Health a Potential Protective Factor? has stated that research has shown that risk of chronic disease increases with age. Mental disorders and chronic disease are highly co morbid, with studies showing reciprocal causal relations. However, research focuses exclusively on combinations of, or a specific, mental illness. Hence, while confronting elderly crisis, their health reality is indeed crude, at some times, and elderly care and compassion, therefore plays a big role within it. Care becomes such an important component in case of elderly health, that often their health develops because of it. Sometimes diseases of the elderly are responsible because of social values. The fact that illness and any kind of physical problems and infirmities that accompany old age is deeply ingrained in the minds of Indian elderly to be an obvious destiny of every aged person and 
therefore it is accepted and considered natural. Karlin and Fuller (2007) in their paper Meeting the Mental Health Needs of the in Older Adults has opined that mental problems of various degrees have been a common characteristics of aged people. Depression and dementia seem to be the most common mental disorders affecting the elderly population where upon this mental issues often encourage various functional disabilities, encumber the health system and impair life-quality of old patients and their relatives. From this juncture we can easily point out that health including its dual facets of physical and mental health is inherently important for the elderly which is the most important factor affecting the elderly quality of life.

Isolation as well as lack of contact with friends, children and other family member affects elderly quality of life in a significant manner. Choi et al (2015) in their study had concluded that isolation or lets say exclusion or detachment often induce degrading mental health contributing to sleeping disturbances as well as depression. They further claimed that social isolation is inversely proportional to longevity and physical mental health too.

Exploring various discourses on elderly health clearly projects a scenario wherein health of the elderly needs to be confronted. In this regard, we feel quality of life of the elderly wherein health is a major component, needs to be a subject of enquiry whereupon problematizing health in terms of quality of life in connection to the senile population needs to be enquired. In the present paper we are exploring the elderly quality of life from health, class and gender context.

\section{Methodology}

The present study is a qualitative study based on narratives and case studies of 20 elderly persons, living in Beleghata area of Kolkata. The study has mainly followed an ethnographic method wherein participant observation was the tool to understand the fiel The study conducted is specifically based on interactions by the researcher and the respective respondents. Qualitative research helps in understanding what people do, why and how they do it, which requires interaction with the field in different kinds of ways. Semistructured interviews, participant observation had been employed in the 
present study. With semi- structured interviews it is possible to get a deeper understanding of the subject by having a dialogue with the interviewee. The data is collected for a period of six months.

\section{Field Description}

Our study is mainly centered in Beleghata area of Kolkata. The research was mainly centered under the road themes of exploring the condition of elderly population who are located in lower rungs of the economic hierarchy. In this regard we chose Ward n. 57 of Beleghata area of Kolkata as the region of our study. In this ward, there are numerous slums. However for the present study we have studied the slum number 44 which was a big slum of the aforesaid ward. At the same time, access to the field became convenient for us as we knew a resident of this slum. The slum number 44 of Ward 57 of Beleghata area is spread over an area of 300 square metres approximately. This slum consists of 350 households comprising of 1200 individuals respectively.

We started our journey where we were helped by Mrs. Supriya Devi, who was resident of this slum. She introduced us to some of the residents of the slum with whom we started interacting. The area is densely populated with a series of small houses (consisting of one or two rooms) located side by side with narrow alleys often acting as the passage to walk to and fro. The area seemed to be a bit congested, shabby and most of the narrow alley was bit dark. In spite of all this issues, what was interesting fact was to see the bond of unity, love and a sort of community feeling being shared by most of the residents there. During our visits, we have seen that most of the women used to talk while washing their utensils or clothes in a common tube well which is mostly located in central place within the alleys. Small, dingy tea stalls were there where we can find men folks chitchatting with a cup of tea as an accompaniment. We started our journey in this way and thereupon chose our respondents.

In the following process of exploration, we have found that sharing lived experiences of own interactions with their families, sons and daughters are often difficult for the senile population in the country. Elderly people are hesitate to share them with unknown people like us. While we were 
exploring our field we too faced resistance from various elderly people, however with a period of time we could make them rely on us and they shared their lived experiences with us often trying to talk in a friendly daughter parent interactive fashion. Herein it can be aptly remarked that problematizing gender, class, caste in the domain of elderly population is indeed difficult which can be explored exclusively with a subjective lens often involving a grounded attitude of the researcher to deal with the respondents who should be given the space to talk, share and live their stories.

In the later table the sample characteristics and features has been described in a tabular format for better comprehension.

\section{Table 1}

Sample characteristics and features.

\begin{tabular}{lllll}
\hline Respondents & Age & Gender & Marital status & \multicolumn{1}{c}{ Living Arrangements } \\
\hline Arati & 72 & F & Widow & Sons and their wives. \\
Bina & 74 & F & Widow & Alone \\
Koli & 75 & F & Married & Husband and sons \\
Diya & 76 & F & Widow & sons \\
Elina & 77 & F & Married & Husband and son \\
Sita & 80 & F & Widow & With sons and daughters \\
Anita & 80 & F & Widow & With a son \\
Anima & 82 & F & Widow & Alone, daughter stays nearby. \\
Indu & 82 & F & Widower & With son \\
Jaydev & 72 & M & Widower & With sons \\
Kamal & 72 & M & Married & With wife and sons \\
Lohit & 75 & M & Widower & With son \\
Madhu & 75 & M & Widower & Alone \\
Nathu & 75 & M & Widower & With son \\
Amit & 76 & M & Married & With wife \\
Piyush & 77 & M & Widower & With a daughter \\
Tarun & 79 & M & Widower & With son and daughter in law \\
Ramesh & 81 & M & Unmarried & With brother's family \\
Samir & 86 & M & Widower & With son and his wife \\
Tapan & 87 & M & Widower & With son \\
\hline
\end{tabular}




\section{Findings}

\section{Transition of values structure}

It is quite an evident phenomenon that with the advent of modernization, there has been a major change within individual value patterns. The values of individualism has increased in such an extent that individuals are often judged on the basis of their utility quotient. In this regard, Knodel et al. (1995); Pandey (2009) opined that socio-economic changes might have brought a significant impact like urbanization, modernisation, increase in women's participation in economic activities, mobility of the younger generation and the growth of individualism but, it is also evident that they are leading to the breakdown of the joint family structure, which used to be the primary support for the elderly in India. From this perspective, Old age is inherently seen as some form of curse and thus elderly people are often ignored, ill treated and often treated as an 'unwanted liability'.

In our field of Beleghata, some of the respondents have also opined in this accord. At the same time, some of the elderly respondents were often hesitating to speak on this issue. Most of them stated 'Barir kechha ar kake bolbo,bolo'(with whom can we share the dark realities of the home. In this regard Arati said:

Once I was having high fever that lasted for days, and was vomiting constantly. I had some serious body aches, and could not sleep because of this. After two days when my friend noticed me, she informed my children to take me to the clinic and get checked to ascertain it's not Dengue, Malaria or Chikungunya which was affecting the entire country at that point of time. They hardly cared. My son gave me a medicine for fever, and it was only when it didn't work and my health worsened and some my friends insisted that he took me to the clinic just to know it was Dengue. The extreme humiliation that I had to face during my illnesswas the time when I received the fright of my life for feeling so much unwanted and valueless.

The aforesaid narrative clearly portrays the grim picture of the elderly people of lower class household. In a study by Pereira (2004) depicting the 
elderly situation in urban communities of Sri Lanka, he concluded that, In case of caring elders, the main problem faced by the lower class elders was economic difficulties. About $42 \%$ of the elders who fall under the lower class face this problem. Elderly population is often ignored by their families, who hardly think of their well being. Most of the individuals feel that degrading health situation of the elderly population is indeed a 'normal affair', an unclassified social construction which can only be analyzed by delving into their behavioral attributes.

Quality of life of the elderly population involves both of their physical health situation as well as mental health state. At the same time food and other supplements are also important for the senile population. Thus elderly care often involves all of it, giving care a 'multi dimensional' character. However, the present society is characterized by the commercialization of care and services. Hence elderly care which was previously provided by the family members is substituted by care giving agencies. Care and services has thus turned into a commodity which has to be purchased. In this regard, Tabatabaei et al. (2011) have opined that elderly care is a complex and costly process. Thus elderly care in lower class household becomes a costly investment which the household decisionmakers intentionally seeks to avoid. In our study, Jaydev who stays with his two sons expressed:

I live with my two sons. Due to sugar and orthopedic problems in my legs, I am unable to walk freely. I cannot starve, hence often asks my daughter in laws to provide me with food. They get angry and insult me while providing food. I do not get fish or eggs. They provide me with rice and a vegetable. Even my sons often mock me and remarks that already you are so aged why can't you stop being hungry, when I hear those remarks, it breaks my heart.

The scion of Hindi Literature Munshi Premchand in his famous short story entitled 'Buri Kaki' had beautifully defined the elderly phase. According to him, the stage of elderly is indeed the reincarnation of childhood phase. From this perspective, it can be aptly remarked that just as a child needs care and compassion, aged people too crave for it. At the same time elderly people do nurture various peevish desires, which unfortunately are proscribed by the society. However, it is indeed queer that 
the same society which legitimizes the same 'emotional Capital' for a child often ignores it for the 'Elderly population'. The modernization theory of aging in this regard had stated that an individual's position in the society is often judged on the basis of the utility or contribution to the society. In more micro sense, an individual 'status in his/her family is judged by his contribution to the institution. Thus as an aged person, individual's utility get consequently diminished, hence his utility for the society in the society also degraded. Thus the discourse of elderly population as docile bodies who should relinquish all their worldly desires are often constructed and distributed within the society (Cowgill \& Lowell, 1972). Society has therefore constructed 'Elderly straitjacket'. According to it every aged person should relinquish all their worldly desires as well as prepare or wait for death which is 'moksha'. They should be spiritually inclined as well as take leave from various world affairs. Thus a 'social Construction of Senility' is prescribed as well as consumed by the society, of which family is an integral institution.

The present problem of the elderly population is that they love to be emotionally attached with their family members, but it has been often seen that the elderly people are treated as unwanted liability in their own families. It is indeed, one of the major reasons behind the increase nuclear families. Times of India, 2012, in this regard have reported that nearly $40 \%$ of the elderly population stays alone or with their ageing spouses Shivadekar (2012). Thus the reality which gets depicted is the increasing rate of loneliness among the elderly population of the country. Savikko (2008) in his paper named 'Loneliness of Older People and Elements of An Intervention and for all its Alleviation' has stated that social isolation is one of the major reasons behind elderly loneliness. Lack of contact and consequent increase in individualist values have acted as the major reasons behind social isolation. It is seen that the society is intolerant towards the elderly population, wherein due to fast life individuals do not have any time to 'invest' on the elderly population. The elderly population faces the problem of exclusion from the mainstream society as well as its members. 


\section{Elderly and Exclusion}

Loneliness can be stated as a constant companion for the elderly population. The present society is characterized by the emergence of nuclear families whereupon the value of individualism strongly cultivates the psyche of family members. From this perspective, it can be seen that the status of elderly people are consequently diminishing and they are often treated as burden. Elderly population is mostly dependent on their children both economically as well as socially which involves the care quotient. Thus families often get irritated to serve this role of care givers. Herein we can sate that there has been a massive change in the status and role of the elderly population in India. In India, there has been a traditional inclination towards gerontocracy which can be briefly summed up as the society where the elderly people are the sole decision makers of the family. Presently we find that gerontocracy is diminishing wih degradingcondition of the aged, whereupon they are often expected to be 'just present' as other material belongings of the house.

In our field we find a very senior woman, aged 85 years, who was so upset with the negative attributes imposed upon her by the young people that she once said to a group of teenage boys who often mocked at her physical deformities,

One day you will be like me, old. Your bones will be cripple, skin chapped and you will be ugly. No one will take care of you. Then, you will realize the pain of old age. Don't make it so difficult for me.

However, instead of understanding her plight, these boys were aggravated for being reminded of his ultimate fate, and treated her more badly by calling her names, and by humiliating her whenever possible, even cursing her for not dying. When a person continues to live even during old age, and something unfortunate happens with the young ones, the elderly people are blamed for it, as if the young are suffering as the aged are surviving.

Sarah Lamb in her pioneering book named 'White Sarees And Sweet Mangoes: Aging, Gender And Body In North India (2000) had provided a brilliant ethnographic piece in the form of a beggar's narrative 'I asked one 
old man, Rabilal, a Mangaldihi beggar of the Muci (leatherworking) caste, what happens when someone gets old, and he replied pessimistically, "When you get old, your sons don't feed you rice". The young girl who cleaned my home, BeliBagdi, responded when I asked her what would happen to her when she became old: "my sons will feed me rice or they won't; there's no certainty". We too get a similar reflection in our respective field too. When we interacted with Madhu, who was a widower of 78 years old. He shared:

I used to work as a sweeper in a government hospital, hence after retirement, I get a meager amount of pension. A part of it I give to my son for household expenditure. I save the other part in the bank with my son. I keep a little amount for my daily expenses including my medical expenditures. In spite of my financial contribution, I am not treated properly by my daughter in law. She never talks properly. I try to help her in household work, but she humiliates. My son and his wife often mock me about my longevity and expenses associated with my food. They mock about my food intake. I feel dejected and often pray God for my death.

The aforesaid narrative vividly shows us that with the progress of civilization individuals are judged on the basis of power, authority as well as financial strength. On the basis of these parameters, elderly population is located in the lower rung of this hierarchy. Hence the easiest solution left for the society and its dominant values is consequential exclusion of aged people, much in coterminous with the traditional Hindu way of four stages of life, wherein elderly phase is visualized in the form of Sanyasa and Banaprastha, wherein their exclusive goal is to await their death and attain 'Moksha' which has been constructed as equivalent to the concept of 'Freedom'.

The above narrative also provides a picture of indirect verbal abuse subjected to the elderly population. From the utilitarian perspective, it can seen that the society is consequently judging people on the basis of their utility or contribution. Once an individual becomes old, his /her utility diminishes and thereupon their status in the family goes through a complete 
makeover wherein they degrades from the position of family head to that of a burden.

\section{Quality of Life}

Quality of life in congruence with elderly population has been a subject of enquiry among various gerontologists. Quality of life of older adults is particularly important in our increasing aging societies, and many scholars argue that it is better that the senile population favours better quality of life over longer living. The World Health Organization (WHO) has attempted both to define the concept and to develop appropriate assessment tools. Developers of these tools have sought to incorporate both subjective and objective elements. Starting from the view that quality of life is a subjective and broad-ranging concept, the WHO sought to identify and test various facets of quality of life and examine in cross-cultural studies how these facets relate to the concept. WHO identified four broad domains as being universally relevant to quality of life, namely physical health, psychological well-being, social relationships, and environment.

The first and the second parameters of WHO's definition on quality of life includes the physical health and psychological health, whereupon psychological well being can also be stated in as mental health in over simplified manner. With reference to the study, physical health can be stated as the 'Visible' health part and the 'psychological' aspect of health may be regarded as the 'invisible' aspect of individual's health. The difference between these two aspects of health can be represented in this manner that physical health is easy to comprehend, diagnose as well easy to treat. On the contrary psychological health is quite a complex affair. Since it cannot be seen directly, it often goes unnoticed, untreated and ignored. In spite of all facts, both the aspect of health is important and should be taken care of .

Health is one of the important variables towards aged people's well being. With regard to the concept of quality of life, we are exploring the facets of physical and mental health of the elderly subjects. In this regard Anima, said 'She is too old and often face difficulties in walking or doing regular household chores. I am forced to seek help from my daughter, who 
stays nearby. She reluctantly helps often mocking and humiliating me. I feel terrible; it destroys my urge to live. I avoid taking her helps but I sometimes I am compelled to do it. Often I compensate her help by giving her some money from my life time savings. In spite of that I can't win her heart. When your soul and heart is consequently destroyed, there is no fault of physiques. You can tolerate all pains inflicted in your body but inflicting pain in your heart is inherently unimaginable.'

In the present day society, one of the numerous problems faced by the elderly population is locomotors problems associated with various forms of Arthritis as well as Osteoporosis. This is a form of health situation which consequently cripples individuals. It is one of the unavoidable health circumstances which can be minimally solved by medication as well as surgeries in the form of replacement which is cost intensive and cannot be afforded by majority of the elderly population. At the same time, it is also seen that for the elderly population beyond the dynamics of physical problems, they are more affected by mental issues. Verbal abuse in the form of emotional cruelty is a common feature in society's attitude towards the elderly population. In our field we found that a considerable number of elderly populations are made to believe that they are unwanted liabilities who should await their death. An elderly social construction can be seen in a lucid way where they are prescribed to refrain from all worldly or material desires.

\section{Conclusion}

Elderly population is rising day by day. Demographically they would accumulate a significant portion of the population pyramid. In this regard, it becomes essential for the society to deconstruct their discourse of 'elderly strait jacket' and construct a new model whereupon this unavoidable reality can be efficiently faced by utilizing them as notable resources. Herein, it becomes essential to describe the notion of elderly strait jacket. Senility has been portrayed as the age of detachment, tranquility and solitude. From the Hindu religious scriptures of four stages of life which had been classified as Brahmacharya, Grihastya, Vanaprashtha and Sanyasa. Wherein elderly phase is coterminous with the era of Vanaprashtha and 
Sanyasa. However, owing to the consequent increase of the elderly population followed by advancements in science and technology, longevity has increased inherently. As a result of this, dependency ratio has been increasing triumphantly. Thus the situation has come where there is a need to bring a change in society's understanding of elderly as a liability to a resource. The notion of active elderly should be adopted whereupon elderly resource can be used much in co termionous with the economic development. At the same time, there is a need to transform the 'dominant' mode of approaching elderly and thereupon include them within the mainstream society, with compassion, care as well as empathy.

In the present study of elderly population in Beleghata slum, we see that most of the elderly population of lower class households was trying to keep them economically engaged as means to meet their ends. It had been also seen that some of the elderly men were engaged physically exhaustive works since that was their exclusive means of survival. In this regard, it can be aptly remarked that there is a need to deconstruct the notion of 'being elderly' wherein the society comprehends them as liability. In Beleghata, elderly populations are compelled to work as an earning member for survival. From here, we can easily deduce that the elderly people of lower class household are indeed in crisis. It is unfortunate that they are often denied as entities and society abuse them in a latent way often not realizing its effects. The role of family is vital in empowering the elderly population but it is an apparent fact that it is the family where in elderly abuse is dominant and which treat them as unwanted burden, in spite of some elderly being active and helping the family. From this we can easily say that elderly should not be imagined as feeble entities but they should be used as resources.

\section{References}

Chaturbhuj, S. (1998). The Socio-pshychological Problems of the Aged. New Delhi: Sarup and Sons.

Choi, H., Irwin, M. R., \& Cho, H. J. (2015). Impact of social isolation on behavioral health in elderly: Systematic review. World journal of psychiatry, 5(4), 432-438. doi:10.5498/wjp.v5.i4.432 
Cowgill, D. O. \& Lowell, D. H. (1972). Aging and Modernization. New York: Appllention-Century-Crofts.

Keyes, L.M. (2005). Chronic Psychological Conditions and. Aging: Is Mental Health a Potential Protective Factor. Aging International, Winter, 30(1), 88-104. Retrieved from http://www.midus.wisc.edu/findings/pdfs/192.pdf

Lalitha, K. (2012). Health Aspects of Elderly: A Global Issue. Journal of Krishna Institute of Medical Sciences and University, 1(2), 1-3. Retrieved from http://www.jkimsu.com/jkimsu-vol1no2/jkimsuvol1no2-Editorial 1-3.pdf

Lamb, S. (2000). White Saris and Sweet Mangoes: Aging, Gender and Body in North India. USA: University of California Press.

Pereira, R. (2004). A Sociological Study on Elderly Care in an Urban Community in SriLanka. Sri Lanka: University of Ruhuna.

Rose, M. R. (1991). The Evolutionary Biology of Aging. Oxford University Press: New York.

Sanderson, W.C. \& Scherbov, S. (2008). Rethinking Age and Aging. Population Bulletin, 63(4), 1-20. Retrieved from https://assets.prb.org/pdf08/63.4aging.pdf

Tabatabaei, O., Peimani, M., Heshmat, R., \& Pajouhi, M. (2011). Status of diabetes care in elderly diabetic patients of a developing country. Journal of Diabetes and Metabolic Disorders, 10, 1-8. United Nations (2009). World Population Prospects : The 2008 Revision, Department of Economic and Social Affairs. Retrieved from http://www.un.org/en/development/desa/population/publications/pdf/t rends/WPP2008/WPP2008_Volume-I_Comprehensive-Tables.pdf United Nations (2016). World Population Prospects : The 2015 Revision, Department of Economic and Social Affairs. Retrieved from http://www.un.org/en/development/desa/population/publications/pdf/t rends/WPP2015/WPP2015_Volume-I_Comprehensive-Tables.pdf

Kafle, B., Sharma, V.D., Jojha, S., Chapagain, M.,Tulachan, P., \& Dhungana, S. (2017). Prevalence of Depression Among Elderly Living in Old Age Homes of Kathmandu Valley and its Association with Socio Demographic Variants. Journal of Psychiatrists' 
Association of Nepal, 35(1), 39-44. Retrieved from https://www.nepjol.info/index.php/JIOM/article/download/8896 17306

Karlin, B.E., and Fuller, J.D. (2007). Meeting the Mental Health Needs of Older Adults. Geriatrics, 62(1), 26-35. Retrieved from https://www.researchgate.net/publication/6577993_Meeting_the_ment al_health_needs_of_older_adults

Knodel, J., Saengtienchal, C and Sittitrai, W. (1995). Living arrangements of the elderly in Thailand: Views of the populace. Journal of CrossCultural Gerontology, 10(1), 80-110. Retrieved from https://www.researchgate.net/publication/30843743

Pandey, M.K. (2009). Poverty and Disability among Indian Elderly:

Evidence from Household Survey. ASARC Working Papers 2009-09, Retrieved from

https://devpolicy.crawford.anu.edu.au/acde/asarc/pdf/papers/2009/WP 2009_09.pdf

Shivadekar, S (2012, December 19). Nearly 1.25 Crore Senior Elderly in Maharashtra. The Times of India. Retrieved from https://timesofindia.indiatimes.com/city/mumbai/Nearly-1-25-croresenior-elderly-in-Maharashtra/articleshow/17679516.cms

Savikko, N. (2008). Loneliness of Older People and Elements of An Intervention and for all its Alleviation. Retrieved from https://pdfs.semanticscholar.org/7ff1/60f35d8fcb35ce1c442a9a5b042 dbb39b1a2.pdf

Sumita Saha. Associate Professor, Presidency University, Somrita Sengupta. Guest Lecturer, RabindraBharati University. Contact Address: 86/1 College Street, Kolkata -700073, India somritasengupta15@gmail.com 